\title{
Mechanisims of asthma and allergic disease - 1079. Evidence of platelet activation in asthmatic patients
}

\author{
Hyun Jung Jin ${ }^{1 *}$, Nami Shrestha Palikhe ${ }^{2}$, Ji Won Lee ${ }^{3}$, Mi-Ae Kim ${ }^{4}$, Yoo Seob Shin ${ }^{5}$, Young Min Ye , Hae-Sim Park \\ From 2nd WAO International Scientific Conference (WISC 2012) \\ Hyderabad, India. 6-9 December 2012
}

\section{Background}

Animal models of allergic asthma indicate that intravascular platelet activation is essentail for the development of allergen induced chronic airway inflammation. P2Y12, the third CysLT receptor, is expressed on platelets and has been an important pathophysiological role in LTE4 mediated pulmonary inflammation. We investigated platelet activation status in asthmatic patients compared to controls.

\section{Methods}

Fifty asthmatic patients and 20 healthy controls were enrolled from Ajou University Hospital, Suwon, Korea Surface expression of P-selectin and P2Y12 on platelets were determined by flowc ytometry. Plasma soluble P-selectin level was measured by ELISA. The asthmatic subjects were classified into two groups depending on high (>mean +2 SD of controls) and low expression of P2Y12.

\section{Results}

The expressions of platelet P-selectin, P2Y12 and soluble $\mathrm{p}$-selectin level were significantly higher in asthmatic patients than in controls, $(p<0.001, p=0.001, p<0.001$, respectively). No significant correlations were found between clinical parameters and platelet activation markers. Expressions of P2Y12 on platelet did not increase significantly after the treatment with LTE4 or aspirin. Higher expression group of P2Y12 had significantly higher peripheral eosinophil count $(P=0.021)$.

'Department of Internal Medicine, College of Medicine, Yeungnam University, Daegu, South Korea

Full list of author information is available at the end of the article

\section{Conclusions}

Platelet activation may play a role in asthma pathogenesis. A possible interaction between platelet and eosinophil via P2Y12 was suggested.

\section{Author details}

'Department of Internal Medicine, College of Medicine, Yeungnam University, Daegu, South Korea. ${ }^{2}$ Pulmonary Research Group, Department of Medicine, University of Alberta, Canada. ${ }^{3}$ St. Marks School, Southborough, USA. ${ }^{4}$ Department of Allergy \& Clinical Immunology, Ajou University School of Medicine, Suwon, South Korea. ${ }^{5}$ Allergy and Clinical Immunology, Ajou University Hospital, South Korea.

Published: 23 April 2013

doi:10.1186/1939-4551-6-S1-P75

Cite this article as: Jin et al: Mechanisims of asthma and allergic disease - 1079. Evidence of platelet activation in asthmatic patients. World Allergy Organization Journal 2013 6(Suppl 1):P75.
Submit your next manuscript to BioMed Central and take full advantage of:

- Convenient online submission

- Thorough peer review

- No space constraints or color figure charges

- Immediate publication on acceptance

- Inclusion in PubMed, CAS, Scopus and Google Scholar

- Research which is freely available for redistribution
() Biomed Central
() Biomed Cental

(C) 2013 Jin et al; licensee BioMed Central Ltd. This is an Open Access article distributed under the terms of the Creative Commons Attribution License (http://creativecommons.org/licenses/by/2.0), which permits unrestricted use, distribution, and reproduction in any medium, provided the original work is properly cited. 